\title{
Reward System and its Effect on Employees Work Motivation in One and Two Star Rated Hotels in Amhara Region, Ethiopia
}

\author{
Belachew Kassahun \\ Department of Tourism and Hotel Management, College of Business and Economics, Bahir Dar University, \\ Ethiopia
}

\begin{abstract}
Star rated hotels are business organizations supported by human resources to deliver the qualified service and realize the dreamed objectives. To provide quality service, understanding motivation is required. Star rated hotels need to rethink their reward strategies to better align them with the new realities in order to improve their employees motivation and retention. This study examined reward system and its effect on employees work motivation particularly employees of one and two star rated hotels. It aimed to investigate whether rewards have an impact on hotel employees work motivation. The finding of the study indicated that there is a positive and significance relationship between reward systems with employee work motivation. Promotion, recognition, benefit, work content, and work condition have a significant effect on employees work motivation but payment has insignificant effect on employees work motivation.
\end{abstract}

Key words: Motivation, Reward, Reward system, star rated hotel

DOI: $10.7176 / \mathrm{JTHS} / 40-04$

\section{INTRODUCTION}

Amhara region is found in historic route and one of the leading tourist destinations in Ethiopia, with a variety of attractions in the nearby Gonder castle, Lalibela rock hewn churches, Lake Tana and Blue Nile River. It is also considered one of the most beautiful and safest regions. But, the country has not been benefited from the tourism sector even if the country has much tourist attractions which are registered by UNWTO as compare to its counterparts in sub-sharan countries. This is observed by the direct contribution to nations GDP which was ETB 30, 476.2mn (World Travel \& Tourism Council: Economic Impact of Ethiopia, 2015). Though, the countries placed a head of Ethiopia have not much attractions which are registered by WNWTO. This directly replicate on the region of Amhara. The development of the tourism sector is accompanied by different sectors. Hence, hotel is the one which facilitates the tourism development.

Hotel is largely dependent on its man power to care customers largly (Datta \& Singh, 2017; Kusluvan, 2003; Tajeddini \& Trueman, 2012). The successfulness of organization is, therefore, determined partly by the customer satisfaction. Excellent service quality is vital to business profitability and survival (Newman \& Cowling 1996). According to Bratton and Gold (2007), effective and well designed reward system can attract, retain and motivate employees thus achieving the strategic objective of the organization. Armstrong (1999) also stated that a well designed and functional reward system is an efficient way to increase employee work motivation and vice versa.

Reward is directly proportion to employee work motivation (Kalim U., Syed U. \& Muahmmad I. 2010). For instance, better the rewards can produce the higher the levels of motivation and greater levels of employee performance at work. Nyandema et al (2014) found that the medical aid as benefits are the most important component of extrinsic benefit affecting employee motivation, but that employee's level of education qualification, period of working in the organization and delivery of targets affect the benefits given to employees. The study concluded that promotion and growth in the organization opportunity is the most important component of career development affecting employee motivation and that career development and coaching facilitate the exploration of needs of the employees. This shows that both intrinsic and extrinsic reward play important role in motivating in organization.

The motivation, which is the result of employees encouragement by cash or other things such as bonuses (e.g. car loan and payment increase), will lead to employees productivity and better performance. Therefore, it is important to recognize which rewarding strategies lead to higher employees' productivity and to enhance their performance. Considering the result of this study, it can be determined that different motivating elements like promotion and bonuses, and suitable payment compensation have significant connection with higher performance (Oyebanju, 2009). 
In Ethiopia, the contribution of star rated hotels for the country is developing in various aspects. This is mainly observed by the direct contribution of Travel \& Tourism to country's GDP in 2015 was ETB30, 476.2mn $(2.2 \%$ of GDP) and this is forecast to rise by $8.9 \%$ to ETB33, $181.3 \mathrm{mn}$ in 2016 (World Travel \& Tourism Council: Economic Impact of Ethiopia, 2016). Though, the direct contribution of hotels was not known to country's GDP since it part of the travel and tourism. Behind these contributions the roles of employees as a service providers appear at first place even if the contribution was not attractive Therefore, this paper aims to analyze the reward system and its effect on employees work motivation by prospective of the employees of star rated hotels in Amhara regional state, Ethiopia

\section{LITERATURE REVIEW}

Human resource is one of the most important resources for organizations survival (Enz, 2012; and Horng et al., 2013). This asset is considered to be the most important asset of any organization. In today's competitive business environment, the success and failure of any organization depends on its human resource and in order to get the efficient and effective result from human resource motivation is necessary (Zaman , 2011). This depicts that employees of hotels are a key resource to organization's success. According to Dessler (2003), without increased motivation and morale of the employees the organization risks losing valuable employees and will be at a disadvantage in attracting potential top talents. This to be happen, effective reward system can play a great role.

Reward can serve the purpose of attracting prospective job applicants, retaining valuable employees, motivating employees, as well as assist in achieving human resource objectives and obtaining competitive advantage (Bratton \& Gold, 2007). This shows that it is mostly important in competitive hotel climate where hotels are fighting for good quality employees in order to improve the quality of teaching and gaining excellent reputation.

Total reward system describes a reward strategy that brings components such as learning and development together with aspects of the work environment, into the benefits package. In the total reward system both tangible and intangible rewards are considered valuable.

Tangible rewards arise from transactions between the employer and employee and include pay, personal bonuses and other benefits. Intangible rewards have to do with learning, development and work experience. Examples of these types of rewards are opportunity to develop, recognition from the employer and colleagues, personal achievement and social life (Armstrong \& Brown, 2006, p.22).

This implies that a reward system is strategy that aims to provide both tangible and intangible benefits to employees which contains monetary benefits and others such as recognition, advancement, experience and personal growth. Therefore organizations including higher institutions must carefully set the reward system to evaluate the employee's performance at all levels and then rewarding them from the tangible pay or intangible satisfaction.

Rewarding is essential as an incentive and an unbreakable motivator to realize the organizational performance. In addition, today, it has been adopted by different organizations in both public and private sections. In downsizing, for instance, doing more with reward is very important to elevate self-esteem and to establish kindness between managers and their employees (Bowen, 2000).

According to Page (2008), rewards can be defined as something that increases the frequency of an employee action which leads to improved performance. He noted that rewards can be very important to employees as it helps to build their confidence and satisfaction in the workplace and reminds them that the extra efforts they put into their work are noticed.

Ballentine (2003) stated that the purpose of rewarding employees is to recognize excellent job performance, provide feedback, make it easier to get work done, to motivate and encourage employees to be more productive and help management achieve their goal. Carraher.et al (2006) also argues that there an effective reward system can retain the high performers in the organization and reward is related to their productivity.

Motivation is another very important term that needs a great attention in an organization. Because motivation can leads to the success of an organization by enhancing the performance of employees through energizing and directing their effort towards some specific goals. It also helps organizations to achieve the desired results by 
increasing the performance and commitment of employees. This is also true for reward system that has a great contribution for the betterment of organizations through motivating, attracting and retaining qualified work force (Mahender, P. \& shabnam, S. 2015). These show that both reward system and motivation are very essential for any organizations. Different scholars define motivation in different ways.

Motivation is an accumulation of different processes that influence and direct behavior of employees to achieve some specific goal (Baron R, A. 1983). Employee motivation is an integral part in a company's development and success. To exploit the overall performance of the company it is imperative for an employer to understand what motivates the employees and how to increase their job satisfaction (Armstrong, 1999). The relevance of motivation is also very crucial to the long-term growth of any educational system around the world. It goes along with professional knowledge and skills, centre competencies, educational resources and strategies as the proper determinants of educational success and performance.

Though some studies of rewards and employees motivation have been conducted but it has been evident that work motivation from one context to another, so it cannot be generalized and the study of its influence on a different settings will always remain a unique one (Jones \& James, 1979;Milton, 1981). For instance, studies concluded that a direct and positive link exists between rewards and employees motivation. It is supported by that reward is directly related to employees' motivation (Farooq et al, 2010). In this regard, when there is a change in the rewarding offer, the work motivation of employees will change too. And while the rewarding ways get improved, the employees' motivation will also get better. Shafiq and Naseem (2011) stated that rewards and employee motivation have positive and significant relationship. There is a significant relationship between recognition and work motivation and satisfaction (Danish \& Usman, 2010). This means motivated staff will have higher work motivation and provide higher care to their customers.

According to Tippet and Kluvers (2009), there is a significant positive relationship between intrinsic rewards and employee motivation. There is a positive relationship between extrinsic rewards and employee motivation (Hafiza, Shah, Jamsheed \& Zaman, 2011).

On the other hand, however, productivity at work decreases as a result of the absence of the suitable incentives (Palmer, 2012). Nadia Sajjad H. et al (2011), revealed on his study, there is a significant and positive relationship between financial rewards and employee motivation. But he had observed that organizations are not offering right amount of financial rewards to their employees. Therefore, it can be concluded that success is not possible without reward systems which are best aligned with the structure and goals of the organization.

Motivation is a milestone in the successes of an organization, but it puts a heavy task for top management. Because, people have different needs, set different goals to satisfy needs and undertake various actions for attainment of the goals. According to Lewis, Goodman and Fandt (1995), an organization's liveliness, whether public or private, comes from the motivation of its employees, although their abilities play just as crucial a role in determining their work performance as their motivation.

Motivation, in the context of work, is a psychological process that results from the interaction between an employee and the work environment and it is characterized by a certain level of willingness. The employees are willing to increase their work effort in order to obtain a specific need or desire that they hold (Beardwell \& Claydon, 2007).

Employee motivation is one of the most essential parts in a company's development and success. In order to maximize the overall performance of the company it is vital for an employer to understand what motivates the employees and how to increase their job satisfaction. It might however be challenging for a company to find out what motivates its employees, especially because different people are motivated by different things (Armstrong, 1999).

The issue of between reward system and employee motivation has been well documented in many literatures. For instance, Gerhart and Milkovich (1992), Colin Pitts (1995), Armstrong \&Murlis (1998), Ballentine (2003), Armstrong and Brown (2006) and Bratton and Gold (2007) concluded that reward system has a significant effect on employee motivation. According to them effective reward system can enhance the motivation of employees. This means organizations with effective reward system can motivate their employees to increase organizational effectiveness.

From the intensive revision of the literatures the following hypotheses were developed. 
H1: Reward systems (Payment, Promotion, Recognition, Benefits, Work content, and work condition) are correlated positively and significantly with work motivation.

H2: Payment has a significant effect on employees' work motivation.

H3: Promotion has a significant effect on employees' work motivation.

H4: Recognition has a significant effect on employees' work motivation.

H5: Benefits has a significant effect on employees' work motivation.

H6: Work content has a significant effect on employees' work motivation.

H7: Working condition has a significant effect on employees' work motivation.

\section{RESEARCH METHODOLOGY}

\subsection{Research Approach and Design}

The quantitative research approach is used to examine the Reward system and its effect on employees work motivation in one and two Star rated hotels in Amhara region, Ethiopia

The research design was descriptive in nature. Descriptive research allows the explanation of phenomena as they naturally transpire and without intervention from the researcher. In addition to being descriptive, the study is also co-relational in design because there is an intention to establish the relationship between independent variables and the dependent variable of employees work motivation. Correlation research aims to discover if there are significant associations between the two variables.

\subsection{Data type and Sources}

To examine the effect of success factors the hotel occupancy, the researcher used both primary and secondary data to effectively achieve the objectives of the study. The primary data are gathered from respondents; employees about the subject using questionnaire. The researcher gathered secondary data which has relationship with the subject, from books, journals, and online references to understand the issue clearly and be able to build a comprehensive background of the study.

\subsection{Population and Sampling}

\subsubsection{Population}

The study consists of employees of one and two star rated hotels in Amhara Regional State. Permanent employees of one and two star rated hotels in regional state constituted the population for the study.

Grading of hotels in Ethiopia is a recent activity. As of other regions, 7 hotels in Amhara region are graded as one and two star in 2015. Therefore, the researcher considered 7 star rated hotels operating in the region-Bahir Dar, Gondar, Lalibela, Kombolicha, Debre Markos, Bure, and Finoteselam.

Table A: List of star rated hotels in different cities.

\begin{tabular}{llll}
\hline SN & Name of the Hotel & City & Star \\
1 & Mountain view Hotel & Lalibela & 2 \\
2 & Papyrus Hotel & Bahr Dar & 2 \\
3 & Quara Hotel & Gondar & 2 \\
4 & Sunnyside Hotel & Kombolcha & 1 \\
5 & Gozamen Hotel & Debre Markos & 1 \\
6 & Tinsae Hotel & Bure & 1 \\
7 & Damot Hotel & Finote Selam & 1 \\
\hline
\end{tabular}

\section{Source: Minister of Culture and Tourism}




\subsubsection{Sample size}

As the information obtained from the targeted star rated hotels' respective human managers, during the months (Late march through early September) of data collection period, the hotel employ only 40-60 employees as permanent employees since the business is more less affected by low season (during which hotel guests are very low in number and variety, and hence the business). Whereas, during peak period of business the hotels have been hiring a casual employees since the hotel customers are relatively in number and variety. The researcher targeted the permanent employees. A simple size based on such fact means roughly about 280-420 guests will visit each hotel in the two months in total.

The researcher used (Yamane, 1967, p. 886) for sample size determination because it is one of the best methods in determining the sample size using the minimum number of the population. By using this formula, the study assumed the sampling error of 5\% and 95\% confidence level, a sample of 165 permanent employees were stratified and selected out of each star rated hotels.

$$
\mathrm{n}=\frac{N}{1+\mathrm{N}(\mathrm{e})^{2}}
$$

Where, $\mathrm{n}$ is sample size, $\mathrm{N}$ is the population size and $\mathrm{e}$ is the level of precision. A 95\% Confidence level and $\mathrm{e}=$ 0.05 , is assumed for the purpose of determining sample size for this Study. Accordingly, the sample size for the study was calculated as follows.

$$
\mathrm{n}=\frac{280}{1+280(0.05)^{2}}
$$

\subsubsection{Sampling technique}

The sampling technique that is used for the study was random sampling techniques. The researcher first applied stratified sampling technique in order to give equal proportion for employees that that has been working as permanent in each star rated hotels. Therefore, the researcher divided the total population in to two strata and applied random sampling technique to select respondents from the each strata. At this time, the formula $\mathrm{n}_{0}=\mathrm{nx}$ $\mathrm{p}_{0} / \mathrm{N}$ was used to select respondents from the strata. Where: $\mathrm{n}_{0}=$ number of respondents selected from the strata, $n=$ sample size. $P_{0}=$ number of population in the strata and $N=$ the total number of population. The population of the strata's' and the selected sample size from each stratum is as follows.

\section{Table 3.1: selected sample by strata}

\begin{tabular}{llll}
\hline Star Rated Hotels & No. of Hotels & Proportion (\%) & Sample size chosen
\end{tabular}

$(\mathrm{N})$

\author{
$1^{\text {st }}$ star hotels
}

$2^{\text {nd }}$ star hotels

Total

\section{4}

3

20
57

43

100
94

71

165

Table B: Sample distribution for research

\subsection{Data collection tools}

The study will use a questionnaire to examine the reward system and its effect on employees work motivation in one and two Star rated hotels in Amhara region. The questionnaire had two parts. The first part included information about biographical data of the respondents like age, sex, nationality and purpose of. The second part included questions directly related with the objective of the study. The later used to gather data about the independent variables and its relation with the dependent variable of employees work motivation. The questionnaire consisted close ended questions. Therefore, in this research, 165 questionnaires were distributed to the permanent employees by the researcher and data collectors at each star rated hotel. 


\subsection{Data processing and analysis}

Both descriptive and inferential statistics were used to analyze the collected data. Descriptive statistics such as percentage, mean, and standard deviation used to analyze the existing situation reward system and its effect on employees work motivation in one and two Star rated hotels in Amhara region. It was used to summarize the demographic characteristics of the respondent and to know the level each reward systems on employees work motivation. Inferential statistics was used to analyze the relationship between independent variables and dependent variable. Analysis of data gathered from respondents with the questionnaire was carried out through the Statistical Package for the Social Sciences (SPSS).

\section{Data Presentation, ANAlysis AND InTERPRETAtion}

In this study of reward systems and employees work motivation in one and two star rated hotels is discussed in detail. 165 self-administered questionnaires were distributed to the respondents and 116 of them were collected with a return rate of $70.3 \%$. It is therefore these 116 questionnaires assumed to be sufficient to be summarized, analyzed and discussed to present respondents' profile, to see how the dependent variable is related to the independent variables.

Table 4.1: Participant's demographic characteristics for permanent employees of one and two star rated hotels

\begin{tabular}{|c|c|c|c|}
\hline \multicolumn{2}{|c|}{ All Respondents } & Frequency & Percent \\
\hline \multirow[b]{2}{*}{ Sex } & Male & 62 & 53.4 \\
\hline & Female & 54 & 46.6 \\
\hline \multirow{4}{*}{ Age } & $20-25$ & 61 & 52.6 \\
\hline & $26-35$ & 39 & 33.6 \\
\hline & $36-40$ & 12 & 10.3 \\
\hline & Above 40 & 4 & 3.5 \\
\hline \multirow{3}{*}{ Educational Level } & 10 and 12 grade complete and above & 28 & 24.1 \\
\hline & Diploma( including TVET level) & 71 & 61.2 \\
\hline & BED/BA/BSC(B- level) & 17 & 14.7 \\
\hline \multirow{5}{*}{ Work Experience } & 1 year or less & 10 & 8.6 \\
\hline & 2 to 4 years & 44 & 37.9 \\
\hline & 5 to 7 years & 31 & 26.7 \\
\hline & 8 to 10 years & 19 & 16.4 \\
\hline & More than 10 years & 12 & 10.3 \\
\hline
\end{tabular}

Table 4.1 above shows that the 116 respondents $53.4 \%$ of the sample respondents are male and $46.6 \%$ of the sample respondents are female. It also depicts the age distribution of the respondents, across the 4 age groups. $52.6 \%$ of the respondents are within the age of $20-25,33.6 \%$ fall within the age of $26-35$. The rest $10.3 \%$ are within the age of $36-40$ and $3.5 \%$ are older than 40 years old. In terms of their educational level, the table also shows that $24.1 \%, 61.2 \%$ and $14.7 \%$ of the respondents have diploma (including TVET level), BA/BED degree and master degree respectively. As most of the employees work experience is more than 2 years. But $8.6 \%$ do not have more than 1 year work experience.

\subsection{Descriptive statistics of reward and employees work motivation}

Descriptive statistic in the form of arithmetic mean and standard deviation were computed for the variables that have been assessed through the questionnaire from permanent employees of one and two star rated hotels. 


\begin{tabular}{|l|l|l|l|l|}
\hline & $\mathrm{N}$ & Grand Mean & Std. Deviation & Rank \\
\hline Payment & 116 & 2.9612 & .72951 & $3^{\text {rd }}$ \\
\hline Promotion & 116 & 2.4310 & .91685 & $6^{\text {th }}$ \\
\hline Recognition & 116 & 2.8190 & .66315 & $4^{\text {th }}$ \\
\hline Benefit & 116 & 2.5718 & .87012 & $5^{\text {th }}$ \\
\hline Work content & 116 & 3.6304 & .72987 & $2^{\text {nd }}$ \\
\hline Work condition & 116 & 3.6897 & 1.03441 & $1^{\text {st }}$ \\
\hline Employee work motivation & 116 & 2.3707 & .57740 & \\
\hline
\end{tabular}

* Where high variables correspond to high motivation

Source: own survey, 2016

As it is indicated in table above, the mean for payment, promotion, recognition, benefit, work content, and work condition ranges from 2.4310to3.6897. The mean values of payment (2.9612), promotion (2.4310), recognition (2.8190) benefit (2.5718), work content (3.6304), and work condition (3.6897). Work condition (3.6897) and work condition (3.6304) are the highest where as promotion (2.4310) is the lowest. Therefore, permanent employees in the current sample from one and two star rated hotels are most likely motivated by work content and work condition. But they are least motivated by promotion in one and two star rated hotels.

\subsection{Inferential Statistics}

In this section the results of the inferential statistical techniques used in the study are presented. Pearson Product Moment Correlation Coefficient was calculated to see the relationship between the independents and dependent variables, and multiple regressions were applied to see that which among the independent variables is most important.

\subsubsection{Correlation}

The Pearson's Product Moment Correlation Coefficient was computed for the purposes of determining the relationship between rewards and employees work motivation.

\begin{tabular}{|l|l|l|}
\hline & \multicolumn{2}{|c|}{ Work Motivation } \\
\hline Variable & Pearson correlation & Significance (2-tailed) \\
\hline Payment & $0.754^{* *}$ & .000 \\
\hline Promotion & $0.587^{* *}$ & .000 \\
\hline Recognition & $0.616^{* *}$ & .000 \\
\hline Benefits & $0.802^{* *}$ & .000 \\
\hline Work content & $0.613^{* *}$ & .000 \\
\hline Work conditions & $0.292^{* *}$ & .001 \\
\hline
\end{tabular}

**Correlation is significant at the 0.01 level (2-tailed)

Source: own survey, 2016 
Reward systems are correlated positively and significantly with work motivation and hypothesis H1 was accepted. As indicated in the table above reward systems is significantly related to payment, promotion, recognition, benefits, and work content and work conditions of rewards.

The results indicated the $\mathrm{r}$ value ranges from 0.292 to 0.802 to explore the relationship between the rewards and employees work motivation, that all the coefficients were positive. The results further depicted in correlation, there were a statistical a significance relationship between the rewards and employees work motivation because all the variables (rewards) p-value 0.001 is less than 0.05 . Therefore the hypothesis is accepted.

\subsubsection{Multiple regression analysis}

On the basis of the results obtained indicating a direct positive relationship between rewards and work motivation, all the dimensions of the instrument were assessed using multiple regression analysis to ascertain the extent to which they explain the variance in work motivation. And also regression analysis is applied to examine the effect of reward system on employees work motivation.

\begin{tabular}{|c|c|c|c|c|c|}
\hline Multiple Regression & & & & & \\
\hline R squared $\left(\mathrm{R}^{2}\right)$ & .878 & & & & \\
\hline Adjusted $\mathrm{R}^{2}$ & .871 & & & & \\
\hline Standard error & 1.03594 & $\mathrm{~F}=130.693$ & Sig. $F=.000$ & & \\
\hline Variables & \multicolumn{2}{|c|}{ Unstandardized coefficient } & $\begin{array}{l}\text { Standardized } \\
\text { coefficient }\end{array}$ & $\mathrm{T}$ & Sig. \\
\hline & $\mathrm{B}$ & Standard error & Beta & & \\
\hline (Constant) & -1.289 & .556 & & -2.318 & .022 \\
\hline Payment & .105 & .075 & .106 & 1.400 & .164 \\
\hline Promotion & -.292 & .067 & -.278 & -4.336 & .000 \\
\hline Recognition & .136 & .061 & .125 & 2.249 & .027 \\
\hline Benefits & .801 & .076 & .725 & 10.485 & .000 \\
\hline Work content & .299 & .036 & .604 & 8.309 & .000 \\
\hline Work condition & -.213 & .067 & -.229 & -3.190 & .002 \\
\hline
\end{tabular}

Source: own survey, 2016

The Beta $(\beta)$ value in the above table indicates the extent of effect of independent variables on the dependent variable (work motivation). Accordingly, benefit reward has a significant effect on employees' motivation and it is followed by work content, promotion, work condition, and recognition rewards. On the other hand, payment has an insignificance effect on employees work motivation.

Table also above displays the estimates of the multiple regression of impact of rewards against its variables for the sample of 116 respondents. The un standardized coefficients B column gives the coefficients of the independent variables in the regression equation including all the predictor variables as indicated below.

\section{Work motivation $(Y)=-1.289-.292($ Promotion $)+.136($ Recognition $)+.801($ Benefits $)+.299($ Work content $)-$ .213 (Work conditions)}

The results also shown the percentage of the variation in work motivation can be explained by the variables entered in the equation $(\mathrm{R}$ - squared $=87.8 \%$; R- squared (adjusted) $=87.1 \%$ ). In overall, the results revealed that all independent variables accounted for about $87.8 \%$ of the variance in employee work motivation. Thus, about $87.8 \%$ of the variation in employee work motivation can be explained by the variables and other unexplored variables may explain the variation in employee motivation which accounts for about $12.2 \%$.

Hypotheses of the study from 2 through 7 were tested and the result has been presented based on the Pearson's Product Moment Correlation Coefficient and multiple linear regression (standardized coefficient of beta and pvalue) results. The researcher has proved their relationship and statistical significance and decided on accepting and rejecting the already developed hypothesis. Therefore, the hypotheses of the study were tested and the result has been presented as follows:

H2: Payment has a significant effect on employees' work motivation.

Table 4.8 above indicated that, payment has a beta value of .106 indicated it has positive and insignificance effect on employees work motivation in one and two star rated hotels with its p-value of 0.164 . So the payment has insignificance effect employees work motivation in one and two star rated hotels and alternative hypothesis is rejected. 
H3: Promotion has a significant effect on employees' work motivation.

As explained in the table 4.8 above the beta coefficient of Promotion is 0.278 and its p-value is 0.000 . The result indicates that promotion has a significance influence on employees work motivation. Since its $p$ - value is significance and below 0.05 , promotion has a significance effect on employees' work motivation in one and two star rated hotels.

H4: Recognition has a significant effect on employees' work motivation.

Based on the table 4.8 above recognition has a beta value of 0.125 this indicate that it has a significance effect on employees' work motivation and the p- value 0.027 is less than 0.05 so the alternative hypothesis is accepted. H5: Benefit has a significant effect on employees' work motivation.

As indicated in the table 4.8 above a benefit has a beta value of 0.725 this indicate that it has a significance effect on employees' work motivation in the college and the p- value .000 so the alternative hypothesis is accepted.

H6: Work content has a significant effect on employees' work motivation.

As explained in the table 4.8 above the beta coefficient of work content is 0.604 and its p-value is 0.000 . The result indicates that work content has a significance effect on employees work motivation in one and two star rated hotels. Accordingly, the hypothesis is accepted.

H7: Working condition has a significant effect on employees' work motivation.

As explained in the table 4.8 above the beta coefficient of work condition is 0.229 and its p-value is 0.002 . The result indicates that work condition has a significance effect on employees work motivation in one and two star rated hotels. Since its $\mathrm{p}$ - value is significance and below 0.05 , work condition has a significance effect on employees' work motivation in one and two star rated hotels and accordingly the hypothesis is accepted.

\section{CONCLUSION}

Employee motivation is a very crucial issue that affects every business organizations in today's competitive environment. To provide an excellent service for their customers and to foster development of tourism in the region one and two star rated hotels as vital place should consider the issue of motivation to satisfy its employees and grasp success. As all we know managing human resource and motivating them equally is hard because of their heterogeneous entity. Even though it is too hard to motivate all employees equally there must be a strategic plan or policy for this matter. Since reward is one of the tools that can be used to enhance the level of employees' motivation.

The study was conducted to examine the reward system and its effect on employees of one and two star rated hotels. The rewards that one and two star rated hotels provides for its employees payment, promotion, recognition, benefit, work content, and work condition. But the reward system of the one and two star rated hotels is poor and employees were not treated well by the hotels. This means, the one and two star rated hotels did provide adequate rewards which includes intrinsic and extrinsic for their employees that motivates them for higher performance. The perception of the hotel employees towards the reward system of the one and two star rated hotels is negative. They believe that the reward system of the one and two star rated hotels is not properly communicated, transparent and fairness. They also felt that the reward system is not externally competitive and appropriate for hotel employees.

Hotel employees were not well satisfied by payment, promotion, recognition, benefit, but they were satisfied with work condition and work content provided by the hotels. Therefore, majority of employees were not satisfied with the existing reward system of hotels. There is a positive relationship between rewards and hotel employees work motivation. This means the payment; promotion, recognition, benefit, work content, and work condition rewards have a positive and significant relationship with the work motivation in one and two star rated hotels.

Promotion, recognition, benefit, work content, and work condition rewards have positive significant effect on hotel employees work motivation but only payment has an insignificance effect on employees work motivation in one and two star rated hotels.

\section{References}

Akemi Yonemura. (2011).The Role of Teacher Training in Technical and Vocational Education and Training (TVET) in Africa. UNESCO IICBA Newsletter, 13 (2):14-17. 
Ali, R., and Ahmed, M. S. (2009). The impact of reward and recognition programs on employee's motivation and satisfaction: an empirical study. International Review of Business Research Papers, 5(4), 270-279.

Armstrong M. \& Brown d. (2006).strategic reward. great britain: kogan page ltd. 1st edition

Armstrong, M. \& Murlis, H. (1998). Rewards Management. A Handbook of Remuneration Strategy and Practice. Great Britain: Kogan Page. $4^{\text {th }}$ Edition

Armstrong, M. (1988): Managing Reward Systems. Buckingham: Open University Press

Armstrong, M. (1999). Hand book of Human Resource Management Practice,. Great Britain: Kogan Page Limited. 7th edition

Armstrong, M. (2009). Handbook of human resource management practice. India: replica press pvt. 1td. 11th edition

Armstrong, M. and Murlis Helen. (2004). Reward Management: Hand book for Remuneration Strategy and Practice, 5th ed., London: Kogan Page limited

Audra H. \& Nelson, M. S. (2010). Total Rewards: It's More Than Just a Pay check.USA: Society for Human Resource Management.

Balletine (2003). Non monetary rewards in the workplace. Retrieved 01, 28, 2013, from studymode.com: www.mightystudents.com

Baron R., A. (1983). Behaviour in organizations. New York: Allyn \& Bacon, Inc.

BD-poly technical college human resource( 2016). Report on overall employment in Bahir dar

Beardwell, Julie \& Claydon, Tim. (2007). Human Resource Management. Great Brian: Pearson Education Limited. 6th edition.

BP-technical college (2016). Booklet on Bahir Dar establishment and service ( in Amharic).

Bratton, J. \& Gold, J. (2007). Human Resource Management: Theory and Practice. New York: Palgrave Macmillan Ltd.

Brown D. \& Armstrong M. (1999). Paying for contribution: real performance- related strategies. London: Kogan Page

Butkus R. T. \& Green, T. B. (1999). Motivation, beliefs and organizational transformation.

Carnegie, D. (1975). Managing through people. New York: Dale Carnegie \& Associates, Inc.

Carolina Mikander, (2010). The effect of reward system on employee motivation in Motonet-Espoo. Ireland: ARCADA

Carraher R., Gibson A. \& Buckley R. (2006). Compensation in the Baltic and the USA . Baltic Journal of Management Vol. 1, 7-23.

Chen, C. C., (1995). New trends in reward allocation preferences: A Sino-US comparison. Academy of Management Journal, vol. 38, 408-428.

Chiang, F.F. and Birch, T.A. (2008). Achieving task and extra-task-related behaviours: A case of gender and position differences in the perceived role of rewards in the hotel industry. International Journal of Hospitality Management, 31( 1): 490-504.

Cohen, J.W. ( 1988). Statistical power analysis for the behavioral sciences. Hillsdale, NJ: Lawrence Erlbaum Associates. $2^{\text {nd }}$ edition.

Collins Pitts, (1995). Motivating Your Organization. USA: McGraw-Hill International, 1st edition. 
Collinson, V. (1996).Reaching Students: Teachers ways of knowing. Newbury Park, CA: Corwin Press.

Danish, R. Q., \& Usman, A. (2010). Impact of Reward And Recognition On Job Satisfaction And Motivation: An Empirical Study From Pakistan. International Journal Of Business And Management, 159-167

De Beer, M.J. (1987). 'n Ondersoek na die rol wat arbeidsomset in die bedryf speel met spesifieke verwysing na werkbevrediging en werksmotivering. Unpublished master's dissertation, University of the Free State, Bloemfontein.

Deposit Taking Micro Finance Institutions, A Case Study Of Faulu Kenya.International

Dessler G. (2003). Human Resources Management. New Jersey: Pearson Education, Inc.

Dessler, G. (2001). Management: Leading People and Organization in the 21st Century. Harlow: Prentice Hall.

Dessler, G. (2008). Human Resources Management, New Jersey City: Pearson Prentice Hall.

Firestone, W. A. \& Pennel, J. R. (1993). Teacher commitment: working conditions and differential incentive policies. Review of Educational Research, 63 (4): 489-525.

Gedefaw, K. (2012). Job Satisfaction of Secondary School Teachers In Ethiopia. Unpublished PhD dissertation, University of South Africa

Gerhart, B. and Milkovich, G. T. (1992). Employee Compensation: Research and Practice. Handbook of Industrial and Organizational Psychology. CA: Consulting Psychologists Press, Vol. 3 (2):1009-1055.

Gibbons, Robert. 1998. "Incentives in Organizations," Journal of Economic Perspectives, 12: 115-32.

Graham, H.T. (1986). Human Resource Management (5 ed.). London: Pitman Publishing

Hafiza, N. S., Shah, S. S., \& Humera, J. (2011). Relationship Between Rewards And Employee's Motivation In The Non-Profit Organizations Of Pakistan. Business Intelligence Journal, 4(2):327-334

Herry, E. and Noon, M. (2001). A Dictionary of Human resource Management. New York: Oxford University Press.

Herzberg, F., Mausner, B. \& Snyderman, B. (1959). The Motivation of Works. New York: John Wiley and Sons. 2nd edition

Hezron, K. \& Wycliffe, M. (2013). The Impact of Reward System on Employee Motivation: A Survey of Commercial Banks in Kenya. International Journal of Business and Management Tomorrow, 3 (1): 272 278.

Janssen, O. (2001). Fairness Perceptions as a Moderator in the Curvilinear Relationships between Job Demands, and Job Performance and Job Satisfaction. Academy of Management Journal, 44 (5): 1039-1050.

Jehanzeb, K., Rasheed, P. M., Rasheed, A., and Aamir, A. (2012). Impact of Rewards And Motivation On Job Satisfaction In Banking Sector Of Saudi Arabia. International Journal of Business and Social Science, 3 (21):272- 278 .

Julie Pallan. (2005). SPSS Survival Manual: A step by step Guide to Data Analysis using SPSS for Windows third edition. Open University press. $3^{\text {rd }}$ edition.

Kerr, Steven. 1975. "On the Folly of Rewarding A, While Hoping for B." Academy of Management Journal 18:769-83.

Khan, K. U., Farooq, S. U., \&Ullah, M. I. (2010).The relationship between rewards and employee motivation in commercial banks of Pakistan.Research. Journal of international studies, 1(14):37-52)

Knut Phillips(1994). How The Dual System Works. Learning to work, working to learn. Malaysia: ISIS Malaysia. 
Kothari, C.R. (2004). Research methodology: methods and techniques. New Delhi, India: new age international publisher. $2^{\text {nd }}$ revised edition.

Lawler, E. E. (2003). Treat people right. San Francisco: Jossey-Bass Inc. McGraw-Hill Irwin.

Lewis, P. S., Goodman, S. H. \& Fandt, P. M. (1995). Management: Challenges in the 21st Century. New York: West Publishing Company.

Luthans. (1992). Organizational Behavior, New York: McGraw-Hill Book co

Mahaney, R C and A L Lederer,( 2006). “The Effect of Intrinsic and Extrinsic. Management

Mahender P. \& shabnam S.( 2015). Effect of Reward Management on Employee Performance in Corporate Sector .Global journal of multidisciplinary studies, 4. Accessed on: www.gjms.co.in.

Milkovich, G., T. \& Newman, J., M. (2004). Compensation. Boston: Richard D. Irwin, Inc. Fifth edition.

Mohrman S.A. \& Ledford,G., E. (1992). Do employee involvement and TQM programs work? Journal for Quality and Participation, 19(1): 6-10.

Mottaz, C. J. (1985). The Relative Importance of Intrinsic and Extrinsic Rewards as Determinants of Work Satisfaction. The Sociological Quarterly, 26(3), 365-385.

Muhammad T.A. \& Sabeen F. (2011). Factors Affecting Teachers Motivation. International Journal of Business and Social Science, 2(1):22-23.

Nadia S., Syed S. \& Humera J. (2011) Relationship between rewards and employee's motivation in the nonprofit organizations of Pakistan. Business Intelligence, Journal 4(.2): 41-48.

Nyandema, Caleb Ochenge and Dr. were, Susan (2014).Role of reward systems in employee motivation in Kenyan deposit taking micro finance institutions, a case study of faulu Kenya. International Journal of Social Sciences Management and Entrepreneurship,1(2): 203-220

Orawan, B. and Phatthanan Chaiyabut N. (2014). Employee Motivation Factors That Affect Job Performance of Suan Sunandha Rajabhat University Employee. International Journal of Social, Behavioral, Educational, Economic, Business and Industrial Engineering, 8(9):2942- 2945.

Page, L. (2008). Do not show me the money? The growing popularity of non-monetary incentives in the workplace .Accessed on: http://www.oppapers com/essays.

Perrin, Towers. (2003). Working Today: Understanding What Drives Employee Engagement: New York: USA report.

Pratheepkanth, P. (2011). Reward System and Its Impact on Employee Motivation in Commercial Bank of Sri Lanka Plc, In Jaffna District. Global Journal of Management and Business Research,11 (4): 1-9

Prendergast, C. (1999), 'The Provision of Incentives in Firms'. Journal of Economic Literature, 37 (1), 7-63

Robbins, S. P. (2001). Organizational Behavior (9th ed.), New York: Prentice-Hall, Inc.

Rowley, J.(2009) Motivation and academic staff in higher education Accessed on: http://www.emeraldinsight.com.

Sekaran, U. (2003). Research Methods for Business: A Skill-Building Approach, fourth edition. Singapore. John

Shafiq, M. M., \& Naseem, M. A. (2011). Association between Reward and Employee Motivation: A case study Banking Sector of Pakistan.

Simons T. \& Roberson Q. (2003). Why managers should care about fairness: The effects of aggregate justice perceptions on organizational outcomes. Journal of Applied Psychology, 88(3): 432-443 
Smyth, R. (1968) financial incentives for salesmen, Harvard Business Review, 46, 109-117

Stone F. M. (2003). The manager's question and answer book. USA: AMACOM.

Suliman, A. (2007). Links between justice, satisfaction and performance in the workplace. Journal of Management Development, 26 (4):294-311

Tella, A., Ayeni, C. O., \& Popoola, S. O. 2007. 'Work Motivation, Job Satisfaction, and Organizational Commitment of Library Personnel in Academic and Research Libraries in Oyo State, Nigeria', Library Philosophy and Practice, 1-16.

Tippet, J., \& Kluvers, R. (2009). Employee Rewards and Motivation in Non Profit Organisations: Case Study from Australia. International Journal of Business and Management, 4(3): 7-14.

Towers Perrin (2005). Total Rewards Communication. USA: Towers Perrin Global Workforce Study.

Voluntary Service Overseas (VSO), (2010). How much is a Good Teacher Worth? A Report on the Motivation and Morale of Teachers in Ethiopia. VSO sharing skills and changing lives, Aluing teachers.

Wood, S. (1996). High Commitment Management and Payment Systems. Journal of Management Studies, 33(1): 53-77

Workineh B. \& Shimels Z. (2010). Academic Staff Reward system. Ethiopian Journal of Education \& Science, $6(1): 13-26$

Workneh A. \& Tassew W, (2013). Teacher Training and Development in Ethiopia: Improving Education Quality by Developing Teacher Skills, Attitudes and Work Condition Young Lives.

WTTC. (2015): Travel \& tourism Economic impact.

Zaidatol A.L., \& Bagheri A. (2009), Entrepreneurship as a center choice: An analysis ofentrepreneurial selfefficiency and intention of university student. European Journalof social science, 9(20):338-346.

Zaman, L. (2011). Human resource management (HRM) in hospitals: a research on the recruitment process of a Bangladeshi hospital. Asia Pacific Journal of Research in Business Management, 2(9), 93-98. 